\title{
The length-weight relationship and condition factor of Toothpony (Gazza minuta Bloch, 1795) from Pabean Bay, Indramayu, West Java
}

\author{
O. D. Soebhakti Hasan ${ }^{1, *}$ \\ ${ }^{1}$ Fisheries Extention Study Program, The Jakarta Technical University of Fisheries, Jakarta, Indonesia
}

\begin{abstract}
The purpose of this study is to specify the length-weight relationship and to evaluate the relative condition factor of toothpony (Gazza minuta Bloch 1795) in Pabean Bay, Indramayu, West Java. The fish collection was carried out monthly from January 2016 to December 2016, and a total of 190 individual fishes were caught using gillnet with mesh sizes varying from 1 to 2 inches. The fish samples ranged from $30-$ $138 \mathrm{~mm}$ in length and $0.41-35.83 \mathrm{~g}$ in weight. The length-weight relationship was $\mathrm{W}=1.5110^{-4} \mathrm{~L}^{2.388}$, and the condition factors of fish varied from $1.1 \pm 0.22$ to $2.03 \pm 2.29$. These results indicate that the growth pattern of toothpony (Gazza minuta Bloch 1795) in Pabean Bay was allometric negative.
\end{abstract}

\section{Introduction}

Pabean bay is located in the northern part of Indramayu, West Java, Indonesia. Roughly 78 species from 39 families have been reported caught in Pabean bay, and one of them is the Leiognathidae family[1]. Gazza minuta (Bloch 1975) from the family Leiognathidae is a small-sized $(<300 \mathrm{~mm}$ in standard length) body frame oval and particularly compressed; dorsal and ventral profiles similarly convex, reasonably deep. Mouth pointing ahead while protracted, with a wonderful caniniform tooth in each jaw[2, 3]. Gazza minuta Bloch, 1795 is known locally as peppered fish, and these species are often encountered in Pabean Bay. However, information about the biological characteristics of these species is very limited.

One important factor in the study of fish biology is the length-weight relationship and condition factor to providing information on the stock condition in fisheries management[4]. Fish biomass is often calculated from abundance by length using the length-weight relationship in the yield assessment [5-7]. The tools for analyzing growth or morphometric that used which many researchers have used the length-weight relationship of fish in an area/water for an individual species such as Mystus nigriceps, Tilapia mossambica, Johnius belangerii, and Sardinella lemuru Bleeker[8-11].

The length-weight relationship provides an overview of the growth pattern and the fish body status condition [12]. The fish body that increases in all dimensions in the same proportion of growth is called isometric allometric. In contrast, negative allometric growth

\footnotetext{
*Corresponding author : otiedylan@gmail.com
} 
means that the fish's body becomes leaner as it gains weight while the fish becomes relatively fatter or deeper due to increasing length is called positive allometric[13].

Condition factor is a value that indicates fish fatness, which can be used as an instrument to show changes in fish condition throughout the year, thereby contributing to fish management activities[14]. This conditioning factor measures various ecological and biological factors on the environment concerning the feeding condition. The higher condition factor means the fish condition is better. Factors that affect the condition of fish such as fish biology (size, age, and sex)[15], season[16, 17], water quality parameters[13, 18], and availability of feeds [19]. The objectives of this study are the length-weight relationship and evaluating conditional factors of toothpony (Gazza minuta Bloch 1795) in Pabean Bay.

\section{Materials and methods}

The study was conducted in Pabean bay Indramayu district West Java Province, Indonesia (Figure 1). Gazza minuta Bloch, 1795 (Figure 2)[20], was carried out monthly from January 2016 to December 2016. Data were taken from a total of 190 individual fishes by measuring each fish's length-weight, and sampling was grouped according to the time of data collection on a quarterly using digital scales respectively were caught using gillnet with mesh sizes varying from 1 to 2 inches.
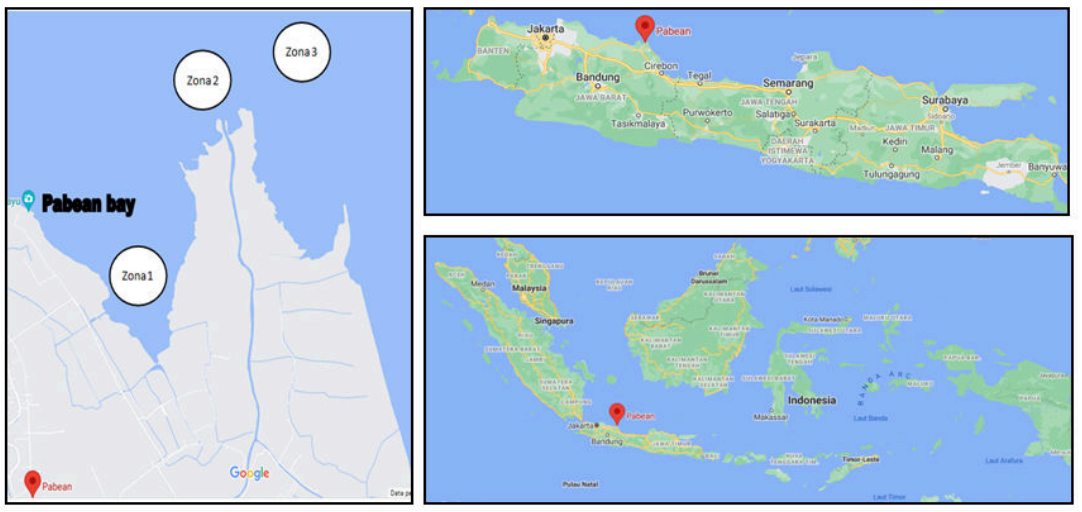

Fig. 1. The site for study in Pabean bay, Indramayu, Indonesia.

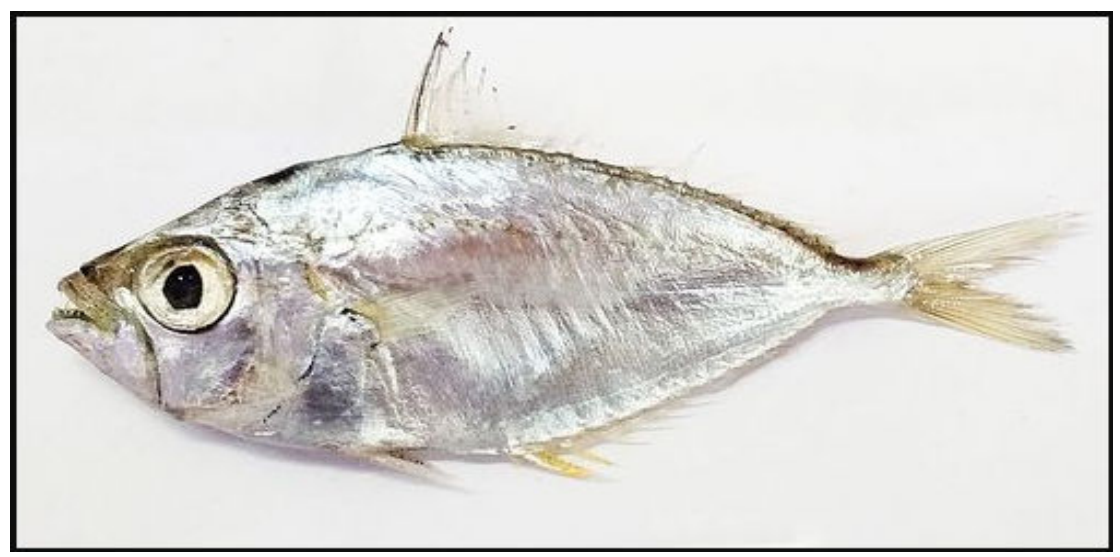

Fig. 2. Toothpony, Gazza minuta (Bloch 1795)[20]. 
The standard length (SL) and total length (TL) have a measurement accuracy of $1 \mathrm{~mm}$ and standard weight with an accuracy of $0.1 \mathrm{~g}$ [21]. The Allometric equation used to determine the relationship between length and weight of fish expressed in the form [19]:

$$
W=a L^{b}
$$

where $\mathrm{W}$ means the total weight $(\mathrm{g})$, a means the coefficient constant for the growth index, $\mathrm{L}$ means the total length $(\mathrm{mm})$, and $\mathrm{b}$ means the slope for the growth coefficient. Biological factor expressed with $b$ value; if a fish body that increases in all dimensions in the same proportion of growth or an equivalent shape and grows increases isometrically $(b=3)$. It shows an allometric positive if the bodyweight increases more than length means that the fish becomes relatively fatter or deeper due to increasing length $(b>3)$. It shows an allometric negative if the body length increases more than weight $(b<3)$ means that the fish's body becomes leaner as it gains weight[21,22].

The equation below is used to evaluate the condition factor of fish[23]:

$$
F=\frac{100 \mathrm{w}}{23}
$$

where $\mathrm{K}$ means the condition factor, $\mathrm{W}$ means the total weight $(\mathrm{g})$, L means the total length (cm), and 3 means the cubic length-weight relationship. The collected data is analyzed using descriptive statistics.

\section{Results}

The total sample fish of Gazza minuta (Bloch 1975) taken are 190 samples. The fish body sizes ranged from $30-138 \mathrm{~mm}$ in length and $0.41-35.83 \mathrm{~g}$ weight. All estimated data of body size, length-weight relationships, and condition factors of Gazza minuta (Bloch 1975) from Pabean bay are shown group quarterly in Table 1 and Table 2.

Table 1. Total length and weight of Gazza minuta (Bloch 1795) Pabean Bay.

\begin{tabular}{|c|c|c|c|c|c|c|c|}
\hline \multirow{2}{*}{ Times } & \multirow{2}{*}{$\mathrm{n}$} & \multicolumn{3}{|c|}{ Total length $(\mathrm{mm})$} & \multicolumn{3}{c|}{ Weight $(\mathrm{g})$} \\
\cline { 3 - 8 } & & Min & Max & Mean \pm SD & Min & Max & Mean \pm SD \\
\hline January - March (Q1) & 80 & 30 & 105 & $62.66 \pm 18.24$ & 0.52 & 15.62 & $4.73 \pm 4.18$ \\
\hline April - June (Q2) & 25 & 34 & 121 & $63.28 \pm 23.52$ & 0.54 & 18.45 & $3.62 \pm 4.70$ \\
\hline July - September (Q3) & 57 & 36 & 138 & $65.63 \pm 21.76$ & 0.52 & 35.83 & $4.44 \pm 6.23$ \\
\hline October - December (Q4) & 28 & 34 & 112 & $57.79 \pm 15.50$ & 0.41 & 11.46 & $3.06 \pm 2.44$ \\
\hline Year (Y) & 190 & 30 & 138 & $62.92 \pm 19.75$ & 0.41 & 35.83 & $4.15 \pm 4.74$ \\
\hline
\end{tabular}

$\mathrm{n}=$ Number of fish samples, $\mathrm{SD}=$ standard deviation

Table 2. Length-weight relationship and condition factor of Gazza minuta (Bloch 1795) Pabean bay.

\begin{tabular}{|c|c|c|c|c|c|}
\hline Times & $\mathrm{n}$ & $\mathrm{a}$ & $\mathrm{b}$ & AllometricPattern & $\mathrm{K}$ \\
\cline { 5 - 6 } & & & & & Mean $\pm \mathrm{SD}$ \\
\hline January - March (Q1) & 80 & $1.6710^{-3}$ & 1.847 & Negatif & $2.03 \pm 2.29$ \\
\hline April - June (Q2) & 25 & $1.7310^{-3}$ & 1.738 & Negatif & $1.27 \pm 0.63$ \\
\hline July - September (Q3) & 57 & $7.910^{-6}$ & 3.075 & Positif & $1.10 \pm 0.22$ \\
\hline October - December (Q4) & 28 & $1.710^{-5}$ & 2.937 & Negatif & $1.36 \pm 0.35$ \\
\hline Year (Y) & 190 & $1.5110^{-4}$ & 2.388 & Negatif & $1.42 \pm 0.89$ \\
\hline
\end{tabular}


$\mathrm{n}=$ Number of fish samples, $\mathrm{SD}=$ standard deviation, $\mathrm{a}=$ constant, $\mathrm{b}=$ slope, $\mathrm{K}=$ condition factor

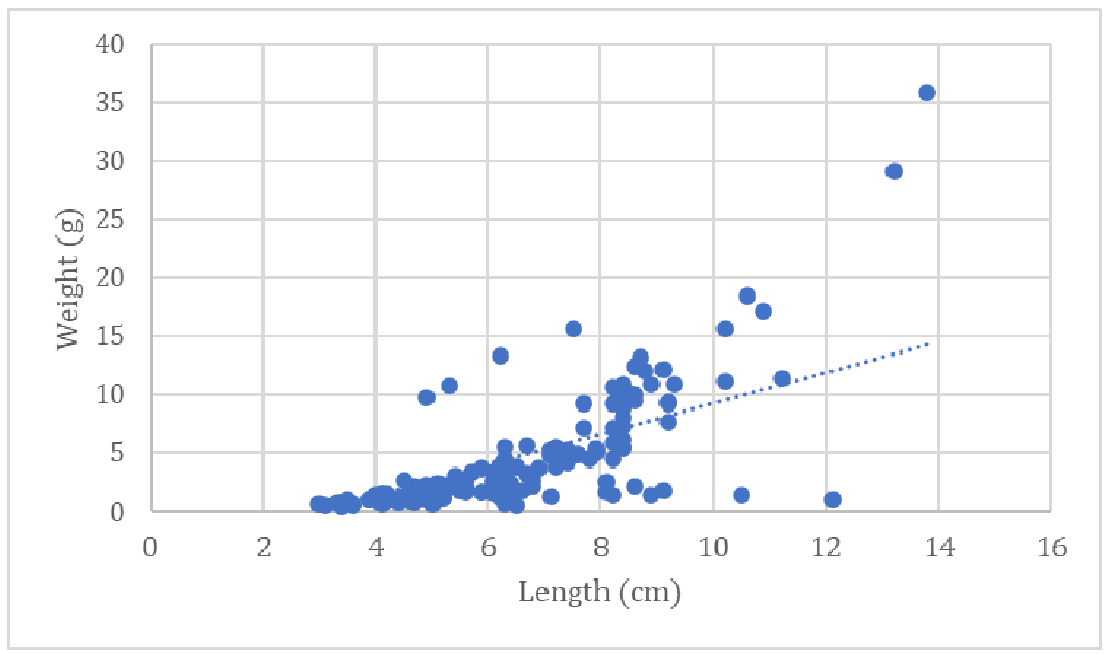

Fig. 3. The relationship between body weight and total length of Gazza minuta (Bloch 1795) from Pabean bay (annual growth pattern Y) that fish grew negatively allometric.

The collected data shown that the length-weight relationship equation for Gazza minuta (Bloch 1795) is expressed as follow $\mathrm{W}_{\mathrm{Q} 1}=1.6710^{-3} \mathrm{~L}^{1.847}, \mathrm{~W}_{\mathrm{Q} 2}=1.7310^{-3} \mathrm{~L}^{1.739}, \mathrm{~W}_{\mathrm{Q} 3}=7.9$ $10^{-6} \mathrm{~L}^{3.075}, \mathrm{~W}_{\mathrm{Q} 4}=1.710^{-5} \mathrm{~L}^{2.937}$, and $\mathrm{W}_{\text {year }}=1.5110^{-4} \mathrm{~L}^{2.388}$. The collected data shown that the length-weight relationship equation for Gazza minuta (Bloch 1795) is expressed as follow $\mathrm{W}_{\mathrm{Q} 1}=1.6710^{-3} \mathrm{~L}^{1.847}, \mathrm{~W}_{\mathrm{Q} 2}=1.7310^{-3} \mathrm{~L}^{1.739}, \mathrm{~W}_{\mathrm{Q} 3}=7.910^{-6} \mathrm{~L}^{3.075}, \mathrm{~W}_{\mathrm{Q} 4}=1.710^{-5} \mathrm{~L}^{2.937}$, and $\mathrm{W}_{\text {year }}=1.5110^{-4} \mathrm{~L}^{2.388}$. The result of the study shows, most of the time had negative allometric growth. The $\mathrm{b}$ value on $\mathrm{Q} 1-\mathrm{Q} 4$ except $\mathrm{Q} 3$ shown that $\mathrm{b}<3$ likewise group $\mathrm{Y}$. The $b$ values on the length-weight relationship equation are subject to the shape and fatness of the Gazza minuta (Bloch 1795). It is also dependent on biological and environmental conditions, temporal sampling factors, season, water quality, and food availability $[4,13,24-27]$.

\section{Discussion}

The results that are shown in figure 3 indicated that the length-weight relationship on annual growth $(\mathrm{Y})$ was a significant positive correlation where coefficient $\mathrm{r}$ ( R square) $=$ 0.6315 .

Several studies have been conducted for several fish species that temperature, spawning season, sex, and species diversity affect the condition factor [7,18,28,29]. The condition factor increases with weight when the temperature drops on the contrary, when the temperature rises, which affects the length-weight relationship $[18,24]$. These factors were not considered in the present study.

The past study showed that Pabean bay is an aquatic ecosystem with characteristics influenced by the environment[1]. Table 2 shows that the condition coefficient is used as an indicator of variability due to the growth coefficient (b), one of the standard fishery practices. The study shows that condition factor $\left(\mathrm{K}_{\text {mean }}\right)$ varied from $1.1 \pm 0.22$ to $2.03 \pm$ 2.29 and most of the time had a condition factor K > 1. Gazza minuta (Bloch 1795) is a small to medium-sized fish with a short life span range from 1.5 to 1.8 years with small $\mathrm{L}$ and large $\mathrm{K}$ values. The past study showed that the short-lived species have a small $\mathrm{L}$ and a high $\mathrm{K}$ value, and long-lived species have a higher L with a low K value[24]. 


\section{Conclusion}

This study result provided the data about the relationship length and weight, evaluating condition factor for Gazza minuta species collected from the Pabean Bay, Indramayu, Indonesia. Almost all length-weight relationships showed a negative allometric growth of fish, indicating that the growth of this fish is getting leaner along with the increase in length and a slimmer body. This may be due to biological and environmental conditions or linked to morphological characteristics specific.

\section{References}

1. L.S. Syafei, R.S. Siregar, M.F. Rahardjo, C.P.H. Simanjuntak, IOP Conf. Ser: Earth and Environ Sci, 404, (2019)

2. K.M. Maung, J. Myanmar Acad 17, 1 (2019)

3. L.A. Al- Shogebai S., Al-mamry J. M. Thalass, Salentina 35, 29-36 (2013)

4. M. Abd Hamid, M. Mansor, S. A. Mohd Nor, Sains Malays. 44, 61-66 (2015)

5. D. Pauly, FAO Fish. Tech. Pap., 234 (1984)

6. J.R. Britton, G.D. Davies, J. Appl. Ichthyol. 23, 624 (2007)

7. J. M. Craig, M.V. Thomas, S.J. Nichols, J. Appl. Ichthyol. 21, 81 (2005)

8. A. Ahmadi, Pol. J. Nat. Sci. 33, 607 (2018)

9. M.F.Rahardjo, C.P.H. Simanjuntak, JIPPI. 15, 135 (2008)

10. A. Jain, A. Mary, C. Angelin, Jeyaseeli, JBINO. 5, 758 (2016)

11. A. Wujdi, Suwarso, Wudianto, BAWAL. 4, 83 (2012)

12. I.S. Kamaruddin, A.S. Mustafa-Kamal, A. Christianus, S.K. Daud, S.M. Amin, L. YuAbit, JFAS. 6, 852 (2011)

13. A. Nehemia, J. Maganira, ABJNA. 3, 117 (2012)

14. M.D.L.A. P. Lizama, A.M. Ambrosio, Braz. J. Biol. 62, 113 (2002)

15. D.J. McKenzie, P.B. Pedersen, A. Jokumsen, Aquac. 263, 280 (2007)

16. S. Heinimaa, Ecol. Freshw. Fish 13, 4 (2004)

17. A.A. Rojas-Herrera, J. Violante-González, D.S. Palacios-Salgado, J. Appl. Ichthyol. 25, 234 (2009)

18. T. Árnason, B. Björnsson, A. Steinarsson, J. Appl. Ichthyol. 25, 401 (2009)

19. R. Froese, J. Appl. Ichthyol. 22, 241 (2006)

20. K. Ueda, INaturalist Research-Grade Observations, iNaturalist.org (2021)

21. N. Jayabalan, C. K. Bhat, Indian J. Fish. 44, 291 (1997)

22. M.Y. Hossain, Z.F. Ahmed, P.M. Leunda, S. Jasmine, J. Oscoz, R. Miranda, J. Ohtomi, J. Appl. Ichthyol. 22, 304 (2006)

23. W. Ricker, Bull. Fish. Res. Bd. Can. 191, 1 (1975)

24. D. Nagarajan, Trans. Eng. Sci. 2, 33 (2014)

25. V.T. Okomoda, I.C.C. Koh, A. Hassan, T. Amornsakun, S.M. Shahreza, Aquac Aquar Conserv Legis 11, 980 (2018)

26. N. Jisr, G. Younes, C. Sukhn, M.H. El-Dakdouki, Egypt. J. Aquat. Res. 44, 299 (2018)

27. E. Lavergne, U. Zajonz, L. Sellin, J. Appl. Ichthyol. 29, 274 (2013)

28. T.D. Harrison, J. Appl. Ichthyol. 17, 46 (2001) 
29. M.Y. Hossain, S. Jasmine, A.H.M. Ibrahim, Z.F. Ahmed, M.M. Rahman, J. Ohtomi, J. Appl. Ichthyol. 25, 117 (2009) 